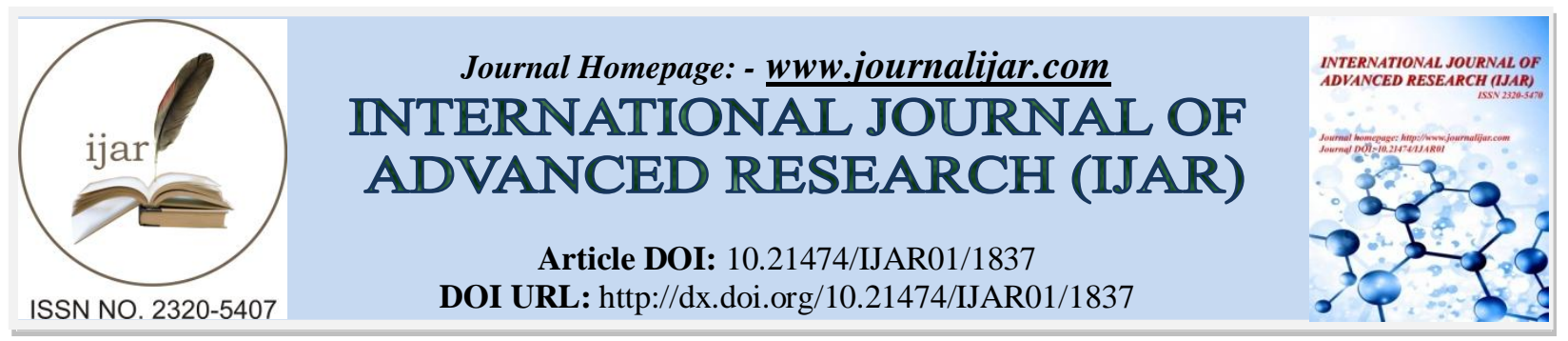

RESEARCH ARTICLE

\title{
GRAZING EFFECT ON FLORISTIC DIVERSITY AND STRUCTURE IN ARID RANGELANDS OF ALGERIA.
}

\author{
Merdas Saifi ${ }^{1,2^{*}}$, Menad Ahmed ${ }^{1}$ and Hanafi M. Tahar ${ }^{2}$. \\ 1. Laboratory of biology and environment, Department of Biology and Ecology, Mentouri Brothers University - \\ Constantine, Ain El Bey, 25017 Constantine, Algeria. \\ 2. Centre of scientific and technical research on arid regions, BP nº 1682 R.P 07000 Biskra -Algeria.
}

\section{Manuscript Info \\ Manuscript History \\ Received: 12 August 2016 \\ Final Accepted: 22 September 2016 \\ Published: October 2016}

Key words:-

Arid rangelands, desertification, grazing, diversity, vegetation cover.

\begin{abstract}
Land degradation is a global issue affecting environment around the world, when occurring in arid and semiarid environment this phenomenon is defined as desertification. Overgrazing can generate a regressive chain reaction leading to degradation of vegetation cover and loss of biodiversity. The use of indicators to assess desertification is suitable to detect the state of the health of rangeland ecosystems. In this study, we assessed species richness and diversity between two habitats (grazed and ungrazed), in addition, we evaluated the effect of grazing on the total vegetation cover, bare ground cover and cooccurrence between the two treatments. Our results indicated that richness, diversity, total vegetation cover and co-occurrence were affected by grazing activity. The high value of bare ground cover indicated a regressive trend, which can be interpreted as a process of desertification. However, the protection from grazing promoted vegetation cover and diversity. It is recommended to use controlled grazing and increase protected zone areas.
\end{abstract}

Copy Right, IJAR, 2016,. All rights reserved.

\section{Introduction:-}

Desertification is a complex phenomenon, including physical and biological aspects, as well as human and social aspects (Mabbutt 1986). According to the United Nations Convention to Combat Desertification, desertification is defined as "land degradation in arid, semi-arid, and dry sub-humid regions". Vegetation degradation is one of the principal processes leading to desertification (Dregne 1998). In semi-arid and arid environments, vegetation degradation is directly related to climate and anthropogenic activities (Le Floc'h 2001; Le Houérou 2001; Gamoun 2013). In semiarid and arid ecosystems, unsustainable livestock farming is an important driver of land degradation (Hanke et al. 2014).

The understanding of grazing effects on plant communities in the Mediterranean arid steppe is still missing. The Mediterranean ecosystems are the most vulnerable to global change (Schröter et al. 2005). In Algeria, more than 20 million hectares are covered by steppe rangelands, these ecosystems are threatened by desertification (Merdas et al. 2015). According to Le Houérou (2001), the present steppe result from a regressive process, the driving forces of this regressive succession are a combination of destructive woodcutting, wild fires, overstocking and clearing, under an increasing anthropogenic pressure, periodically worsened by recurrent climatic droughts.

Corresponding Author:- Merdas Saifi.

Address:- Laboratory of biology and environment, Department of Biology and Ecology, Mentouri 
Overgrazing is the most important factor of degradation in arid lands of Australia, Africa, Europe and Asia. Land degradation in Africa is much more associated with overgrazing, the example is the North Africa, where overgrazing has a negative effect on the ecosystem (Aidoud \& Touffet 1996; Gamoun 2013). The grazing activity has a role in changing the composition of plant communities by reducing the abundance of palatable species and promoting less palatable species (Milton \& Hoffman 1994). In addition, grazing can reduce the perennial vegetation cover and leading to the exposure of the soil more to wind and water erosion.

Facing this great problem, Algerian authorities implemented many policies and techniques for the management and protection of rangelands. The management practices of steppe rangelands are provided by the High Commission for the Development of Steppe (HCDS) since 1994 (Amghar et al. 2012). The most common management technique is grazing exclosure (protection from grazing), since this technique is cost effective and easy for its implementation.

Therefore, the use of a set of vegetation indicators is essential for the measurement of the sustainability of grazing systems (Yayneshet \& Treydte 2015). In addition, the vegetation is a good indicator of an ecosystem's overall function in arid and semi-arid areas (Zuo et al. 2008).

Overall, our study aims to have more understanding of the plant communities in arid Mediterranean steppe by giving more effective indicators to assess desertification and contributing to the conservation of ecosystem functioning. In this study, we addressed the following research questions: (1) what is the effect of grazing by livestock on plant communities (species richness, abundance of species, annual species, and leguminous species) of steppe rangelands? (2) Is grazing exclosure an effective management practice?

\section{Methods:-}

\section{Study area:-}

The study area is located in the Central Steppe of Algeria (Fig 1). The climate of the study area is arid. Climatic data were obtained from the nearest weather station of Boussâda (period 1988-2014). The data indicated that climate condition is characterized by a single dry season along the whole year, with an average temperature ranging from $8.88^{\circ} \mathrm{C}$ to $32.30^{\circ} \mathrm{C}$ for January and July months, respectively. The average of annual rainfall is $184 \mathrm{~mm}$, the lowest value is recorded in July with $5.14 \mathrm{~mm}$, and the highest value in September with $28.21 \mathrm{~mm}$. Land use is dominated by livestock farming along the year. The most common soil type in the study area is calcimagnesic soils (Halitim1988). 


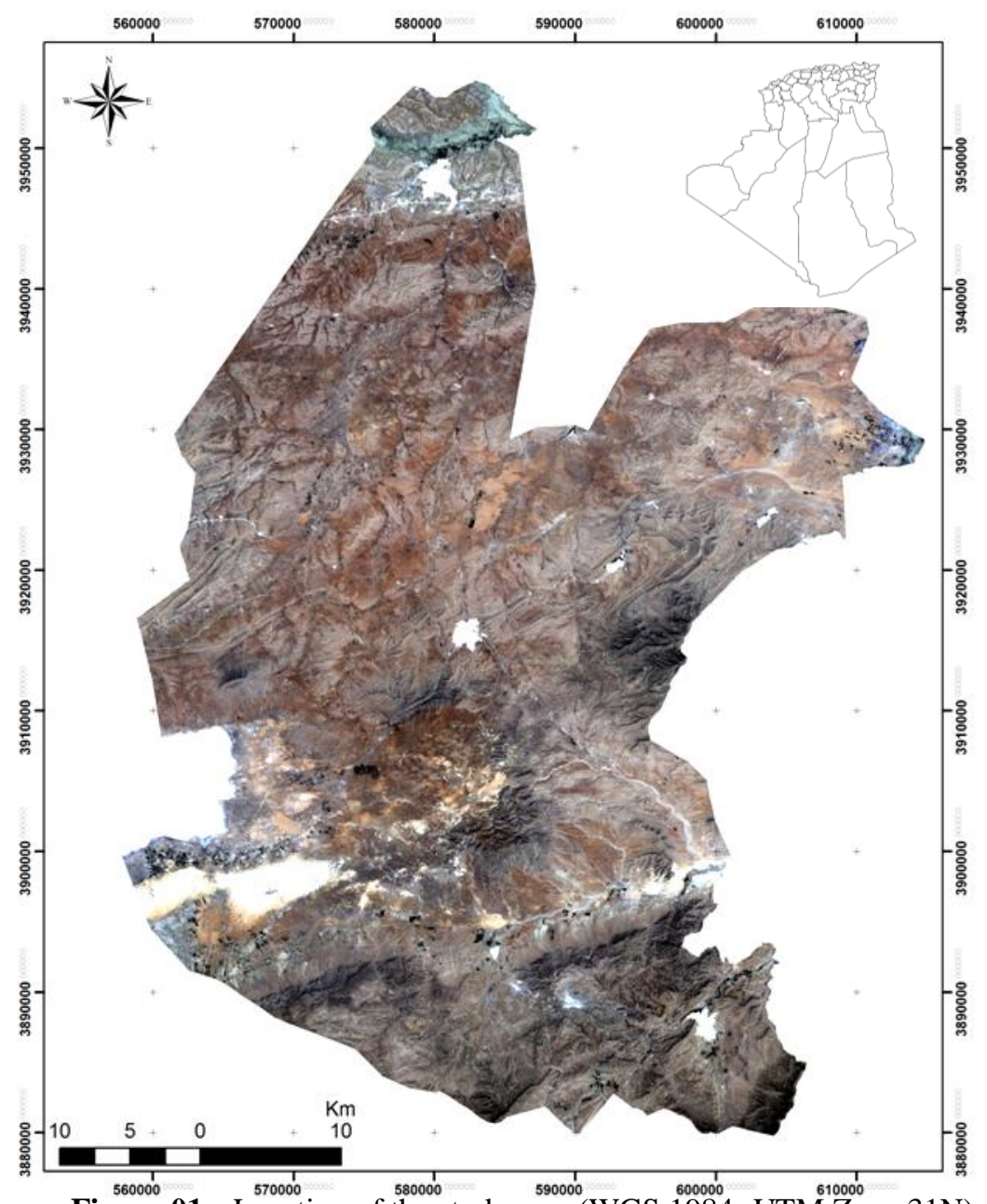

Figure 01:- Location of the study area (WGS $1984-$ UTM ${ }^{5600000000}$ Zone $31 \mathrm{~N}$ )

A steppe community in plains, dominated by the perennial grass Stipa tenacissima, characterizes the vegetation. In addition, mountains are covered by an open forest dominated by, Pinus halepensis, Quercus ilex and Juniperus phoenicea. The phytogeographical point of view, the proposed area is located at the border of two floristic regions: the Mediterranean region in the north and the Saharan-Arabian region in the south (Kaabeche 1996).

\section{Data collection:-}

The vegetation survey was conducted between April and May 2014, during active growth period of the plants. In total, we sampled 30 transects, 15 transects were sampled in protected areas and 15 were performed in freely grazed areas. We used the Point-Intercept Method to estimate plant abundance and richness. We recorded the identity of plant species every $20 \mathrm{~cm}$ for each transect.

\section{Data analysis:-}

Plant species richness (S) was estimated in each transect by the number of recorded species. For plant species diversity, we measured Shannon index and Pielou's evenness for grazed and protected areas. Plant cover is calculated according to the number of hits of all plant species, the co-occurrence is estimated according to the number of times where two or more species were found together in the same point. The obtained data were subjected to one-way analysis of variance (ANOVA) to test the existence of significant differences in all parameters for the two treatments protected and grazed areas using the R software (R Development Core Team, 2016).

\section{Results:-}

In this study, 101 species were recorded in the plant community studied belonging to 81 genera and 27 families. Eleven families were represented only by one species. Asteraceae family represents $26 \%$ of the total of species, 
followed by Poaceae by $18 \%$ and Fabaceae representing $8 \%$ of species. The remaining 13 families represent $13 \%$. Stipa tenacissima was the most abundant species with 4803 records the equivalent of $33.25 \%$ and it was found in all sampling sites. The second most abundant species is Anacyclus cyrtolepidioides with 1661 records (hits) representing $11.5 \%$ of the total abundance (Table 1 ).

Table 1:- The most abundant species representing $90 \%$ of total records.

\begin{tabular}{|l|c|c|}
\hline Scientific name & Contacts & \% \\
\hline Stipa tenacissima & 4803 & 33,3 \\
\hline Anacyclus cyrtolepidioides & 1661 & 11,5 \\
\hline Stipa tortilis & 1140 & 7,9 \\
\hline Malva aegyptiaca & 1109 & 5,6 \\
\hline Artemisia herba-alba & 806 & 4,5 \\
\hline Plantago albicans & 649 & 2,9 \\
\hline Filago spathulata & 423 & 2,8 \\
\hline Koeleria pubescens & 410 & 2,4 \\
\hline Helianthemum salicifolium & 343 & 2,1 \\
\hline Micropus bombicinus & 300 & 1,9 \\
\hline Stipa lagascae & 280 & 1,1 \\
\hline Noaea mucronata & 160 & 1,0 \\
\hline Artemisia campestris & 148 & 1,0 \\
\hline Asteriscus pygmaeus & 144 & 0,9 \\
\hline Atractylis prolifera & 132 & 0,9 \\
\hline Schismus barbatus & 132 & 0,9 \\
\hline Plantago ovata & 127 & 0,9 \\
\hline Eruca vesicaria & 126 & 0,7 \\
\hline Herniaria fruticosa & 104 & \\
\hline
\end{tabular}

Protected areas had the highest value of species richness with 37 species and mean value of $30.20 \pm 5.85$. The mean richness value for grazed areas was $18.67 \pm 4.98$ with a maximum value of 26 species. The ANOVA test revealed that species richness was significantly different between grazed and protected areas $\left(F_{1,28}=33.83, P=0.000003\right)$ (Fig 2, a). The mean value of the Shannon index for ungrazed areas was $2.19 \pm 0.24$ and $1.83 \pm 0.38$ for grazed areas. This index differed significantly between the two treatments $\left(F_{1,28}=9.51, P=0.004\right)$ (Fig 1, b). The Pielou's evenness indicated that there were no significant differences between grazed and ungrazed areas $\left(F_{1,28}=0.297, P=\right.$ 0.59 ) (Fig 1, c), the mean value of evenness in ungrazed areas was $0.65 \pm 0.06$ and $0.63 \pm 0.09$ for grazed habitats respectively.

(a) Richness

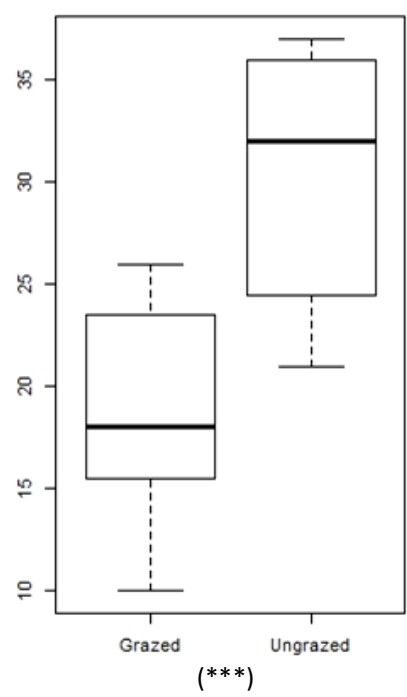

(b) Shannon

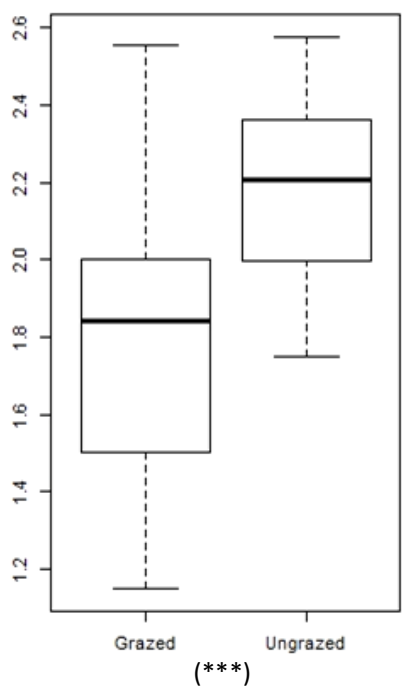

(c) Evenness

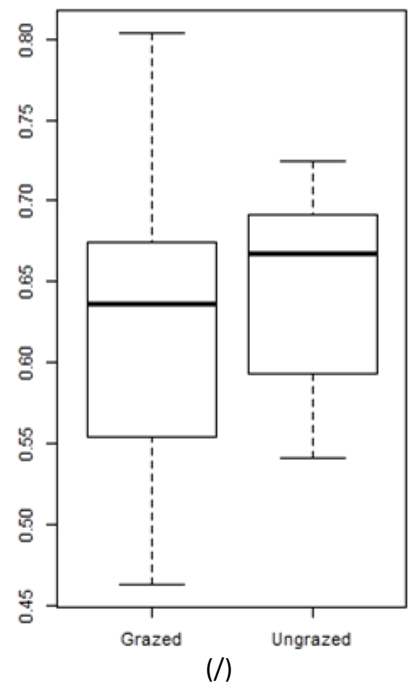

Figure 01:- Comparison of diversity measures for grazed and ungrazed areas in the study area. (a) Richness, (b) Shannon index and (c) Evenness. The symbol $(* * *)$ represents the existence of significant differences for the ANOVA test, (/) indicates no significance for ANOVA test. 
The results indicated that grazing activity affected significantly the total vegetation cover between grazed and ungrazed areas. The same result was found in the bare ground cover. For the cover of the most abundant species Stipa tenacissima, results indicated that there were no significant differences between the two treatments, whereas, for co-occurrence the ANOVA test revealed a significant difference between grazed and ungrazed areas (Table 2).

Table 2:- Structure parameters of the plant community between protected and grazed areas.

\begin{tabular}{|l|c|c|c|}
\hline Parameters & Ungrazed & Grazed & Significance \\
\hline Total vegetation cover & $50.69 \pm 6.46$ & $36.95 \pm 9.30$ & 0.0001 \\
\hline Bare soil cover & $49.41 \pm 6.46$ & $62.83 \pm 9.89$ & 0.0001 \\
\hline Stipa tenacissima cover & $16.58 \pm 6.54$ & $15.04 \pm 7.01$ & $\mathbf{0 . 6 4 9}$ \\
\hline Co occurrence & $65.80 \pm 30.05$ & $20.66 \pm 16.91$ & 0.0001 \\
\hline
\end{tabular}

Bold value indicates that there is no significance for ANOVA test between the two treatments.

\section{Discussion:-}

Overgrazing is considered as the most important factor of degradation in arid parts of Australia, Africa, Europe and Asia. Land degradation in Africa is much more associated with overgrazing, the example is the North Africa, where overgrazing has a negative effect on the ecosystem (Aidoud \& Touffet 1996; Gamoun 2013). Grazing has a role in changing the composition of plant communities by reducing the abundance of palatable plants and promoting ephemeral plants (Milton \& Hoffman 1994). Heavy grazing can lead to the deterioration of the vegetation cover by consuming plant species and trampling (Su et al. 2015). The reduction of vegetation cover and its replacement by annual plants makes the soil more susceptible to wind and water erosion in consequence, the processes of desertification.

Our study in arid rangelands of Algeria showed that grazing activity induced a significant reduction in species richness and Shannon diversity index. However, grazing did not have an effect on the evenness. Our results are in concordance with those of (Gamoun 2013; Salemkour et al. 2016) and following the model of (Olff \& Ritchie 1998) in which grazing in arid environment can lead to the reduction of diversity. The reduction of richness and diversity can lead to the deterioration of palatable species (Tarhouni et al. 2010) and the decrease of the pastoral quality of rangelands. The effect of grazing on plant species richness and diversity is more accentuated under dry conditions (Tarhouni et al. 2010).

The cover of bare ground tended to increase with grazing gradient, representing more than $62 \%$ of the total cover. Thos high value of the bare ground cover indicates that soils in grazed areas are more exposed to degradation processes. In grazed areas, grazing activity is carried out throughout the year; in such condition, the pressure of herbivores is maintained continuously leading to low vegetation cover and high proportion of bare ground. The cover of Stipa tenacissima did not show any differences between grazed and protected areas, indicating that grazing did not affect Stipa tenacissima. However, the co-occurrence parameter negative tendency under the effect of grazing. In ungrazed areas, co-occurrence is more important, this can be due to the suppression of disturbance activity of herbivores and the absence of trampling. Aidoud et al. (2006) reported that Stipa tenacissima provides refuges for many species like Sedum sediforme and Xeranthemum inapertum; this is consistent with our results where the most important co-occurrence records were those of Stipa tenacissima with other species. This is why the perennial grass Stipa tenacissima is considered as a key species in arid rangelands of Algeria.

Many studies have indicated that protection from gazing activity had a positive effect on plant community diversity in arid environment (e.g. Amghar et al. 2012; Gamoun 2013). This finding is confirmed by our study where protection from grazing improved significantly the plant species richness and diversity. The absence of disturbance (defoliation, trampling) stimulates the development of plant species, which recover new bare areas which in turn increased total vegetation cover. The recovery was not only restricted to plant species and vegetation cover, but there is an improvement in pastoral quality; increase in pastoral value and proportion of leguminous species (results not shown).

These findings show that high values of bare ground recorded in the study area are an indicator of desertification processes. Therefore, controlled grazing is recommended as well as the increase of areas of protected zones as indicated by (Le Floc'h 2001; Slimani et al. 2010). 


\section{References:-}

1. Aidoud, A., Le Floc'h, E., \& Noel Le Houerou, H. 2006. Les steppes arides du nord de l'Afrique. Sécheresse 17: 19-30.

2. Aidoud, A., \& Touffet, J. 1996. La regression de l'alfa (Stipa tenacissima L.), graminée pérenne, un indicateur de désertification des steppes algériennes. Sécheresse 7: 187-193.

3. Amghar, F., Forey, E., Margerie, P., Langlois, E., Brouri, L., \& Kadi-Hanifi, H. 2012. Grazing Exclosure and Plantation: A Synchronic Study of Two Restoration Techniques Improving Plant Community and Soil Properties in Arid Degraded Steppes (Algeria). Revue D Ecologie-La Terre Et La Vie 67: 257-269.

4. Dregne, H.E. 1998. Desertification assessment. In Lal, R., Blum, W.H., Valentine, C., Stewart, B.A. (ed.), Method of Assessment for Soil Degradation, pp. 441-458. New York.

5. Le Floc'h, E. 2001. Biodiversité et gestion pastorale en zones arides et semi-arides méditerranéennes du Nord de 1 ' Afrique. Bocconea 13: 223-237.

6. Gamoun, M. 2013. Grazing intensity effects on the vegetation in desert rangelands of Southern Tunisia. Journal of Arid Land 6: 324-333.

7. Halitim, A. 1988. Sols des régions arides d'Algérie. Alger.

8. Hanke, W., Böhner, J., Dreber, N., Jürgens, N., Schmiedel, U., Wesuls, D., \& Dengler, J. 2014. The impact of livestock grazing on plant diversity: an analysis across dryland ecosystems and scales in southern Africa. Ecological Applications 24: 1188-1203.

9. Le Houérou, H.N. 2001. Biogeography of the arid steppeland north of the Sahara. Journal of Arid Environments 48: 103-128.

10. Kaabeche, M. 1996. Les relations climat-végétation dans le bassin du Hodna (Algérie). Acta Botanica Gallica 143: 85-94.

11. Mabbutt, J.A. 1986. Desertification indicators. Climatic Change 9: 113-122.

12. Merdas, S., Bolghobra, N., \& Lakhdari, F. 2015. Thee Green Dam in Algeria as a tool to combat desertification.Planet@Risk 3: 3-6.

13. Milton, S.J., \& Hoffman, M.T. 1994. The application of state-and-transition models to rangeland research and management in arid succulent and semi-arid grassy Karoo, South Africa. African Journal of Range \& Forage Science 11: 18-26.

14. Olff, H., \& Ritchie, M.E. 1998. Effects of herbivores on grassland plant diversity. Trends in Ecology and Evolution 13: 261-265.

15. R Development Core Team. 2016. R: A language and environment for statistical computing. $R$ foundation for statistical computing, Vienna, Austria. http://www.R-project. org.

16. Salemkour, N., Aidoud, A., Chalabi, K., \& Chefrour, A. 2016. Évaluation des effets du contrôle de pâturage dans des parcours steppiques arides en Algérie. Revue D Ecologie-La Terre Et La Vie 71: 178.

17. Schröter, D., Cramer, W., Leemans, R., Prentice, I.C., Araújo, M.B., Arnell, N.W., Bondeau, A., Bugmann, H., Carter, T.R., Gracia, C. a, de la Vega-Leinert, A.C., Erhard, M., Ewert, F., Glendining, M., House, J.I., Kankaanpää, S., Klein, R.J.T., Lavorel, S., Lindner, M., Metzger, M.J., Meyer, J., Mitchell, T.D., Reginster, I., Rounsevell, M., Sabaté, S., Sitch, S., Smith, B., Smith, J., Smith, P., Sykes, M.T., Thonicke, K., Thuiller, W., Tuck, G., Zaehle, S., \& Zierl, B. 2005. Ecosystem service supply and vulnerability to global change in Europe. Science (New York, N.Y.) 310: 1333-1337.

18. Slimani, H., Aidoud, a., \& Rozé, F. 2010. 30 Years of protection and monitoring of a steppic rangeland undergoing desertification. Journal of Arid Environments 74: 685-691.

19. Su, H., Liu, W., Xu, H., Wang, Z., Zhang, H., Hu, H., \& Li, Y. 2015. Long-term livestock exclusion facilitates native woody plant encroachment in a sandy semiarid rangeland. Ecology and Evolution 5: 2445-2456.

20. Tarhouni, M., Salem, F. Ben, Belgacem, A.O., \& Neffati, M. 2010. Acceptability of plant species along grazing gradients around watering points in Tunisian arid zone. Flora: Morphology, Distribution, Functional Ecology of Plants 205: 454-461.

21. Yayneshet, T., \& Treydte, a C. 2015. A meta-analysis of the effects of communal livestock grazing on vegetation and soils in sub-Saharan Africa. Journal of Arid Environments 116: 18-24.

22. Zuo, X., Zhao, H., Zhao, X., Guo, Y., Yun, J., Wang, S., \& Miyasaka, T. 2008. Vegetation pattern variation, soil degradation and their relationship along a grassland desertification gradient in Horqin Sandy Land, northern China. Environmental Geology 58: 1227-1237. 